\title{
AN IDENTITY EQUATION IN ORGANIZATIONAL LIFE: TURKEY CASE OF ARTICLE
}

\author{
DOI: 10.17261/Pressacademia.2020.1203 \\ RJBM- V.7-ISS.2-2020(5)-p.116-127
}

\section{Hazal Koray Alay}

Independent Researcher, PhD, Istanbul, Turkey.

hazalkoraygenc@hotmail.com, ORCID:0000-0002-6638-3089

Date Received: April 8, 2020

Date Accepted: June 16, 2020

To To cite this document

Alay, H.K., (2020). An identity equation in organizational life: Turkey case of article. Research Journal of Business and Management (RJBM), V.7(2), p.116-127.

Permanent link to this document: http://doi.org/10.17261/Pressacademia.2020.1203

Copyright: Published by PressAcademia and limited licensed re-use rights only.

\section{ABSTRACT}

Purpose - The main purpose of the present study was to investigate cultural, religional and political identity differences in the role of the diversity climate perceptions, individual career outcomes and organizational effectiveness outcomes.

Methodology - The research is a quantitative research in terms of the data collection and analysis method.

Findings- It is determined that cultural, religious and political identity has a differentiating effect on perception of diversity climate, individual career outcomes and organizational effectiveness outcomes. As a result, this study which attempts to measure the perceptions shaping the attitudes and behaviors of employees with different identity structures, proceeded its tests means of quantitative research method and found its theoretical foresight supported.

Conclusion- All participants of the labor market need to understand that people are diverse and unique, and that diversities are not sufficient to justify discriminatory policies such as exclusion, marginalization and humiliation.

Keywords: Identity, cultural, political and religional identity, diversity climate, individual and organizational outcomes JEL Codes: M10, M14, M54

\section{INTRODUCTION}

"Why are diversities so important for organizations?" is one of the most important questions waiting to be answered in today's business life. Diversities are important for organizations and there are many factors that reveal this importance. Among these factors are changing world dynamics, free mobility of the workforce, differentiation of the socio-cultural structures in organizational life. Especially, the changing position of women and their increasing number in business, the presence of employers from various political, religious, cultural identity and different sexual and emotional orientation. In the circumstances, organizations with uniform and homogeneous structures are replaced by organizations dominated by heterogeneous structures. In this context, organizations have to see these diversities and they must manage those diversities properly and they have to create a supportive diversity climate. Sustaining an organizational atmosphere that supports diversities would increase individual career outcomes and organizational efficiency. This situation will enable members of the organization to interact and work together in harmony. Thus, it will be opened up the acquirement of competitive advantage and long-term sustainability for organizations. For that reason, it is necessary to meet the need to manage diversities effectively.

In the 1990s, diversity management has been brought to the agenda with the studies carried out in USA. Diversity management is based on the idea that employees, who differ in many aspects such as ethnic identity, culture, sexual and emotional orientation, appearance, disability, educational status, lifestyle should be managed in a way that they work in harmony, add value to the organization and provide competitive advantage (Thomas, 2010,3). This idea suggests that when diversities are managed in a proper way, it will make a positive effect in both individual and organizational outcomes. 
An important issue that comes up with the diversity management is the perception of diversity climate. Diversity climate is an important issue for labor force differences and it has become wildly popular in recent years. As it is well known, organizational

climate is about employees' perception regarding their working environment. On the other hand, the diversity climate is related to the employees perception the opportunities or obstacles the organization offers who are considered different within the organization.

According to Cox, the diversity climate is the overall perception by which employees think that their organizations put policies, practices and procedures into practice for the elimination of discrimination as well as the enhancement and protection of individual differences. Cox $(1993,35)$ in his book Cultural Diversity in Organization, presented his model of transactional diversity climate and examined it under three factors. These are categorized as: Individual factors - identity, prejudice and discrimination, stereotypes, personality - group/intergroup factors - cultural differences, ethnocentrism, group conflicts - and organizational factors - organizational culture, structural integration, human resources system. Cox (1993,35), who argues that the perceived diversities at work has an impact on individual and organizational outcomes, classifies these outcomes as follows: Individual career outcomes include factors such as job and career satisfaction, organizational commitment, promotion status, job performance ratio. Organizational effectiveness includes factors such as efficiency, quality of work, creativity and innovation, absenteeism, intention to quit, communication and harmony between employees, market rate, feasibility of objectives. Cox's model has blazed the trail for many studies related to diversity climate (Thomas, 2010; Orlando, 2000; Prahalad and Bettis, 1986; Gilbert et al., 1999; Barak, 2000; Özbilgin et al 2013; Sürvegil, 2010; Dreachslin et al., 2004; Agars and Kottke, 2004; Richard, 2000; Mckay et al. 2009; Yeo, 2006).

This study addresses the diversities at the individual level in the context of identity structures. Previous studies largely focused on identity differences originated from gender and ethnicity. This study examines individual identity differences in the context of cultural identity, political identity, religious identity in Turkey as a developing country with various cultural structures and identities. As one of the main problems in developing countries, the fact that minorities in the working life are exposed to discriminatory, exclusive and marginalizing practices, and the scarcity of laws and regulations increases the significance of this topic. The study evaluates how employees with different identities perceived the diversity climate in their workplaces. Then, it focuses on the effects of differences in identity structures on individual outcomes such as organizational commitment and job satisfaction as well as organizational outcomes such as intention to quit, communication and collaboration between employees, behavioral innovation and organizational performance. The outcomes subjected to examination were selected based on a previously conducted meta-analysis study.

\section{LITERATURE REVIEW}

\subsection{Diversity Climate}

Hyde and Hopkins $(2004,61)$ define the concept of diversity as the degree of heterogeneity of employees within the organization. The diversity climate, which has been a very popular subject recently, is "the overall perception by which employees think that their organizations put policies, practices and procedures into practice for the elimination of discrimination as well as the enhancement and protection of individual differences" (Lauring and Selmer,2011). Empirical research on the diversity climate is quite limited. Present studies typically focus on in its precursors rather than the consequences of the diversity climate. The first study on the diversity climate was conducted by Kossek and Zonia $(1993,12)$. The aim of this study is to enhance the representation of minority groups within the organization. The second important study is about scale of diversity climate. The perception of diversity climate scale was developed by Mor Barak et al. $(1998,23)$. This scale assesses the extent to which an institution supports diversities to provide an inclusive and fair climate, based on social identity and intergroup relations theories.

According to Sliter (2014), the diversity climate in an organization reflects the common perceptions of employees regarding the results of various forms of workplace harassment and discrimination against diversities. From this point of view, organizations with a positive diversity climate do not show tolerance towards harassment and discrimination, while organizations with a negative diversity climate overlook marginalization, harassment and discrimination of others. Pitts and Wise (2010) state that the diversity climate consist of the psychological climate (perceptions, attitudes and beliefs about diversities) and behavioral climate (ways of interaction of different racial and ethnic groups in a given environment). From this perspective, the concept of diversity climate covers the whole of attitudes, perceptions and beliefs developed against diversities between groups in the work environment. 


\subsection{Identity Structure}

Identity acquires its meaning as the answer given to this specific question 'Who am I?'. In addition, identity have attempted to define it within the framework of the individual life and considerations (Bauman, 2017,25). Every person has an identity, which cannot be limited to the information contained in the official records. Foremost among them are belongings. This sense of belonging could be felt towards a nation, an ethnic and religious group, a more or less large family, a vocation, an institution, a certain social circle, a city, a village, a sports team or professional organization, a group of friends, a union, a political party, group of people sharing the similar sexual orientations or similar physical disabilities, a community got harmed by same negative effects. The list is quite long and even unlimited (Maalouf, 2018, 16). Each of these has different degrees of significance. Certainly none of them are pointless. They are defined as the genes of the soul, provided that it is known that most of them are not innate. They are also the building blocks of personality. Personality is one of the main factors that determine identity.

As Milan Kundera aptly explains in his classic aphorism, the identity of any person comes into being his existence hurts. This aphorism proves that at every stage of life, people have some attitudes towards their belonging and wounds that determine the hierarchy between them (Mollaer, 2014, 8). People do not forget when they are persecuted because of their religion, when they are humiliated or mocked because of their skin color or accent. Identity consists of a wide variety of belongings, but at the same time, identity is a phenomenon in which we experience it as a whole. According to Maalouf, "a person's identity is not the result of successive juxtaposition of some self-ordained belongings, identity is not a patched rag bag, it is a pattern drawn on a stretched canvas" (Maalouf, 2018, 26).

\subsubsection{Cultural identity}

Our cultural identities formed by the culture itself are the focal point of the social identities we belong to. The power of our cultural identity shows the degree of importance we attach to our culture while defining ourselves (Gudykunst, 2015,23). The cultural identity of the people in America reflects the degree to which they identify themselves as Americans whereas the fact that Turkish people describe their cultural identities by referring to their sub-cultures actually indicates its multicultural structure. In this context, if one attempts to classify cultural identity in Turkey, ethnic-based identity structures such as Turkish, Kurdish, Armenian, Laz, Greeks, Romany, Caucasian, Arabic, Bulgarian, Bosnian, Pomak and Albenian ethnicities. In comparison with other minorities, the most crowded ethnical and cultural identity in Turkey is Kurdish identity.

\subsubsection{Political identity}

Individual identities are under the domination of collective identity. Individuals attempts to participate in social life by displaying an essentialist attitude are also resistance against the impositions of social identity. This resistance testifies to the effort for the affirmation of individual existences in overall society. In this context, the melting pot in which individual identity and collective identity intertwine is political identity (Pamuk, 2017, 90).

Another aspect that shapes political identity of Turkish population is ideological perspective. It is also accepted that religious identity plays a role in the construction of political identity. In this context, when people classify political identities in Turkey they use categories such as nationalist, conservative, liberal, democrat, socialist and anarchist (Cotton, 2017.98).

\subsubsection{Religious identity}

Religion has been one of the most important institutions affecting individuals and societies since the beginning of human history. Societies has always believed in a religion, albeit in various ways, and performed religious rituals. Although its exact number is not known today, it is thought that there are about five thousand religions and sects in the world (The Book of Religions, 2014).

There is no single form for religion. Every religion has different forms of meaning. Religion itself is open to different interpretations. In this context, Islamic identity also cannot be interpreted as a monolithic structure. People who believe in the same God in their faith creates different religious ways by their interpretations formed in their deeds and life practices. It testifies that Sunni Muslim and Shia Muslim (Alevism), two different forms of Islam, construct different forms of meaning in different geographies (Pamuk, 2017: 68-69). Alevis composes the largest segment among religious minorities in Turkey. (Minority Right Group International 2011 Report). Other religious identities that continues their existence in Turkey are Jews, Christians, Assyrians, and Yazidis.

Although they take different forms, religious arrangements and rituals determine the lifestyle of the society and the individual, and encompass all areas of the society. But modern societies emphasize that religion should take a backseat in the public sphere. However, it is wrong to consider modern societies completely anti-religious, secularist and materialist. Because, even though it 
has been thrown into the background, religion remains as a significant part of daily life by undergoing different changes. In other words, large-scaled social transformations in modernity prompted traditional religious structures to evolve into a new understanding of holiness (Arslan, 2015: 55-72). In this context, different religious identities such as atheism, deism, agnosticism, paternalism and materialism become increasingly popular.

\subsection{Individual and Organizational Outcomes}

In the literature, we frequently encounter in organizational life the concepts related to the individual and organizational outcomes. It is obvious that diversities in identity are related to outcomes such as job satisfaction, organizational commitment, the intention to quit work, the environment for communication and cooperation, behavioral innovation, organizational performance, yet this relationship has not been adequately studied. The issue of job satisfaction as the summation of various elements like wages, the physical working conditions (Lawler, 1976, 345), all the positive and negative characteristics regarding the level of success, the awards given for these achievements, the relationships maintained with colleagues and managers because of this work (Blum and Naylor, 1986,128), is mostly connected with different identities such as diversities in tenure, employment status, age, income and gender. However, other identity diversities have not been taken into account. Organizational commitment (Smith et al. 1983,23), defined as the degree to which an employee embraces the values and goals of a particular organization, and the desire to invest in the organization in the long run and remain a member of it, has been studied more in the context of racioethnicity, gender and age. The intention to quit (Tett \& Meyer, 1993, 259; Vandenberghe et al. 1998,1314), which reflects a subjective decision that employees would consider leaving their organization if they are not satisfied with their working conditions, has been also evaluated with similar identity diversities. Communication and cooperation, as the fundamental and compulsory functions of any organization, have been associated with diversities such as employment status, human resource practices, language and religion. Behavioral innovation, which enables the formation of an innovation culture among individuals, teams and management circles, has been associated with the frequency of innovation proposals that employees would generate as a result of original thinking/behavior, managerial attitudes towards innovation proposals, and the methods that management takes in adopting innovations (Yavuz, 2010,143). Organizational performance (Ensari et al. 2016) defined as the compilation of many variables such as communication and collaboration between employees, culture of the organization, corporate policies and practices, leadership structure, the environment for creativity and innovation, organizational climate with high organizational commitment is mainly associated with demographic diversities.

In this framework, this study is an attempt to provide an alternative model in the literature by considering the individual career outcomes and organizational effectiveness outcomes in the context of diversities in cultural, political and religious identities.

\subsection{Conceptual Framework and Hypotheses}

Theories and conceptions play a guiding role in explaining the research topics. Accordingly, the fundamental theories and institutions on which the diversities are based in the Social Psychology and Behavioral Science literature are listed as "Social Identity Theory, Intergroup Relations Theory, Symbolic Interactionism Theory, Social Categorization Theory, Equality Theory, Ethnic Identity Theory". Social Identity Theory and Equality Theory contribute significantly to the creation of our conceptual framework since its model focuses on identity structures among employees.

Social identity theory is one of the fundamental theories of social psychology trying to explain the behaviors between groups, group memberships and processes for group formation. People tend to divide others into groups and give superiority to their own group. The underlying reason is the tendency for people to make positive self-assessment. When people construct this positive self-assessment they consider their own group as superior and identify themselves with this group. At this point, the concept of social identity comes to the forefront. Social Identity Theory, developed by Henri Tajfel and John Turner in the mid-1970s, explains this concept in the most comprehensive way. They called as minimal group paradigm, demonstrates the fact that even normally non-existent artificial groups are sufficient for people to favor their own groups, affirming their superiority. If we evaluate this situation in terms of working life, the dominant or minority status of the groups brings along a series of individual and organizational advantages and/or disadvantages.

Similar to the social identity theory, Equality Theory, Adams $(1963,430)$ argues that the individual perception for equality is not independent from the values and norms of his/her social group. Every individual has a learning story. However, to the extent that he/she learns the same values, social norms, the same language and culture from the group he/she belongs, his/her psychological responses become similar to theirs. In this context, individual identity testifies to one's existence. Individual identity affects our world of thought, our social status and our working life. 
There is a common point upon which these theories that diversities in individual identity have some consequences for individuals and organizations.In this framework, the perception for diversities among minority and majority groups differ in terms of their identity structures within organization life. On the one hand, minority groups are considered as the group that increases the value of the workforce, while the dominant majority is seen as the source of resistance to change. In this case, leaders who manage to balance them are building multi-participatory heterogeneous organizational structures with an organizational climate that would benefit from diversities (Freeman and Huang, 2014,305). Ellemer and Rink (2016,39), in their research they focused on diversities in terms of gender and ethnic identity, indicate that heterogeneous business groups are more creative, innovative and have more qualified performances compared to homogenous groups. On the other hand, they emphasize that not all diversities have equal benefits and advantages, and their study result could take many forms and ways.

It is determined that the perception regarding organizational support for diversities has a positive relation with individual outcomes such as organizational commitment, job and career satisfaction (McKay et al. 2007; Gonzalez and Denisi, 2009; Buttner et al. 2019); and a negative relation with organizational outcomes such as intention to quit, absenteeism, conflict, and performance (Mc Kay et al. 2008; Boehm et al. 2014; Kaplan et al. 2011; Madera et al. 2016, Ensari et al. 2016). On the other hand, Avery et al. (2013) in their study found that women and minorities lose the chance to land a job due to prejudices regarding their identity and are directly disqualified in recruitment processes. A similar study reveals that psychological contract violations occurred among employees with different ethnic identities in the USA are related to the awareness and perception regarding racial and other diversities in identity. If minorities have a positive perception regarding justice, organizational commitment and communication-oriented cooperation increases however, by contrast if the same perception is negative, efficiency decreases and the intention to quit increases (Buttner et al. 2010,321).As a result of this views, basic predictions of this study is that the diversities in the identity structures of the employees affect individual and organizational outcomes. Individual outcomes includes job satisfaction and organizational commitment; organizational outcomes consists of intention to quit, communication and cooperation environment, behavioral innovation and perceived organizational performance. In this study, identity structures of employees are evaluated in three categories, respectively cultural identity, religious identity and political identity. Based on the preceding discussion, the following two hypotheses:

$\mathbf{H}_{1}$ :Identity structures of employees have impact on individual career outcomes.

$\mathbf{H}_{2}$ : Identity structures of employees have impact on organizational efficiency outcomes.

According to Akerlof and Kranton, people's identities define who they are and their social categories, describing their instant, daily interactions for several years, lifelong and generations $(2016,16)$. As a result of these interactions, individuals define, evaluate and classify themselves by taking into account the social group they belong to. Thus, they identify with the group in which they placed themselves. This identification constitutes the social identities of individuals (Turner, 1985, 89). Identity structures differ in many contexts such as gender, age, marital status, educational background, sexual orientation, ethnicity, religious belief, political or ideological view.

According to Mead's $(1934,21)$ Symbolic Interactionism Theory, employees attach meaning to the organization according to the results of social interactions they experience in the organization. The meaning attributed to the organization itself contributes to the formation of the perception regarding this climate. In this context, the diversity climate is a metaphorical concept that explains the interaction between minorities and others within the organization. When organizations develop and establish policies, rules or practices, some of them pay attention to employees' satisfaction, while others simply choose to pursue their own interests. However, each employee develops various attitudes and behaviors against organizational practices that directly or indirect (somehow) affect himself and other employees. In this regard, the opportunities and obstacles offered to those defined as "others" within the organization determine the formation of diversity climate perception (Sürvegil, 2010).In this context, the diversities in the identity structures of the employees affect the perception of the diversity climate within the organization. Based on the preceding discussion, the following hypothesis has been developed:

$\mathbf{H}_{1}$ :Identity structures among employees have a differentiating effect on the diversity climate perception 
Figure 1: Research Model

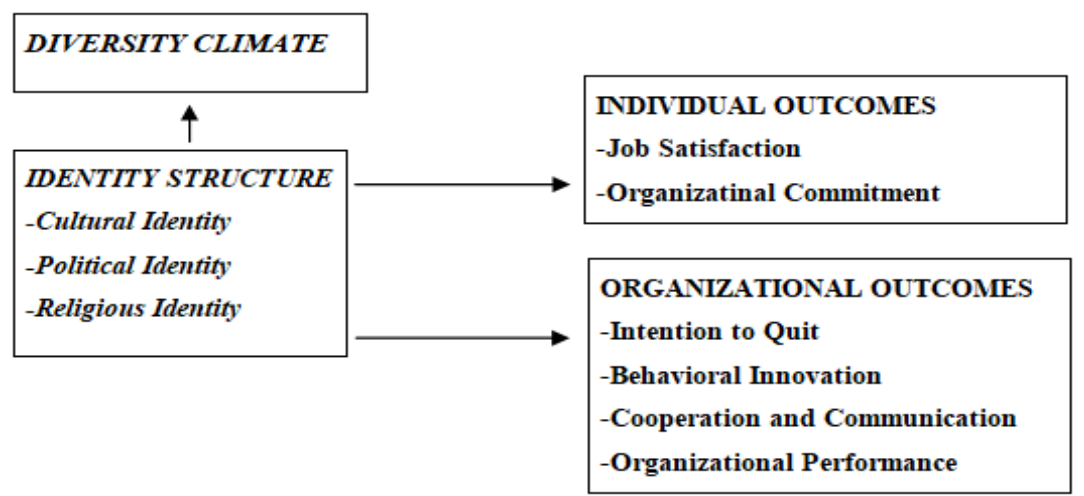

\section{DATA AND METHODOLOGY}

\subsection{Sample}

The sample of the study consists of 532 employees from different sectors in Istanbul. The reasons for choosing Istanbul as the sample area can be listed as follows:

- Istanbul is a metropolis hosting the greatest proportion of Turkish labor force

- Istanbul is a city that enables the cohabitation of people with different cultures and identities

- Istanbul is the engine of Turkish economic development

- Istanbul draws immigration to a very a great extent.

By means of the snowball sampling method, the study reached these sample size and sent a survey via mail and 534 of these group responded to this survey. After identifying 2 missing and incorrectly coded questionnaires, 532 employees were included in the research. Frequency distribution was examined in order to define distribution of employees identity. In this context, the distribution of employees' identity orientation diversities can be seen in Table 1:

\section{Table 1:Frequency Distribution of Identity Structures}

\begin{tabular}{|l|l|c|c|}
\hline \multirow{4}{*}{ IDENTITY STRUCTURES } & Frequency & Percentage \\
\hline \multirow{4}{*}{ Cultural Identity } & Turkish & 274 & 51.5 \\
\cline { 2 - 4 } & Kurdish & 173 & 32.5 \\
\cline { 2 - 4 } & Immigrant & 43 & 8.1 \\
\cline { 2 - 4 } & Armenian & 42 & 7.9 \\
\cline { 2 - 4 } & Total & 532 & 100 \\
\hline \multirow{4}{*}{$\begin{array}{l}\text { Religious } \\
\text { Identity }\end{array}$} & Sunni Muslim & 300 & 56.5 \\
\cline { 2 - 4 } & Alevi & 72 & 13.5 \\
\cline { 2 - 4 } & Atheist & 64 & 12.1 \\
\cline { 2 - 4 } & Deist & 53 & 9.9 \\
\cline { 2 - 4 } & Christian & 22 & 4.1 \\
\cline { 2 - 4 } & Agnostic & 21 & 3.9 \\
\hline
\end{tabular}




\begin{tabular}{|l|l|c|c|}
\hline \multicolumn{1}{|c|}{ Total } & 532 & 100 \\
\hline \multirow{4}{*}{ Political Identity } & Conservative & 60 & 11.2 \\
\cline { 2 - 4 } & Nationalist & 75 & 14.2 \\
\cline { 2 - 4 } & Social Democrat & 136 & 25.6 \\
\cline { 2 - 4 } & Liberal & 94 & 17.6 \\
\cline { 2 - 4 } & Socialist & 167 & 31.4 \\
\cline { 2 - 4 } & Total & 532 & 100 \\
\hline
\end{tabular}

The resulting distribution of cultural identity in our data is in parallel with Turkey's cultural structure. Similarly, distribution of religious identity is also in parallel with the social structure in Turkey as demonstrated by the fact that Sunni Muslims constitute $60 \%$ of the population. It was expected that the number of Christians and Armenians would be close but almost half of Armenians are Deist in terms of their religious identity.

\subsection{Measures}

Diversity climate scale was developed by McKay Avery and Morris (2008) which contains 4 items. Organizational commitment scale was developed by McKay et al. (2007) which contains 4 items. Job satisfaction scale was developed by Brimhall, Lizano and Mor Barak (2014) which contains 4 items.Intention to quit work scale was developed by McKay, Avery, Tonidandel, Morris, Hernandez, and Hebl (2007) which contains 2 items. organizational performance scale was developed by Erdem, Gökdeniz and Met (2011) which contains 7 items.perception for the communication and cooperation environmentscale was developed by Avcl (2005) which contains7 items. Behavioral innovation scale was developed by Wang and Ahmed (2004) which contains 4 items. The reliability coefficients of the scales used in the research are over 0.80 .

\subsection{Analysis}

The research is a quantitative research in terms of the data collection and analysis method. In the test of our research model, Explanatory Factor Analysis method was used to evaluate the validity of the scales.Cronbach Alpha $(\alpha)$ model was used in reliability analysis. Independent Sample T-Test and One Way Analysis of Variance (ANOVA) are used to examine whether the identity structures of employees have a differentiating effect on the variables in the research model and Sheffe and Tukey-B Tests to find the origin of the difference. In the event that the Sheffe and Tukey-B Tests from the SPSS analysis did not yield any findings, we also made evaluations by looking at the mean differences. Prior to analysis, we determined classifications in the data set as follows: For cultural identity categories are Turkish and others (Kurdish, Armenian, Immigrant); for religious identity they are Sunni Muslim and others (Alevi, atheist, deist, Christian); and for political identity they are conservative + nationalist, social democrat + socialist and liberals.

\subsection{Results}

Explanatory factor analysis was performed on the items of the all variables of the research model. Two measures were used to test the fit between the data and the factor analysis to be performed: Bartlett Test of Sphericity (BTS=1850.649 for diversity climate, BTS(= 2130,649 for organizational effectiveness outcomes, BTS=1501,928 for individual career outcomes; $p<.00$ ) and Kaiser Meyer Olkin (KMO value for the overall variable was over the 0.80 ,indicating a very good fit of factor analysis). Cronbach's alpha value is 0.918 for job satisfaction and 0.941 for organizational commitment. The Cronbach's alpha value is 0.906 for behavioral innovation; 0,904 for communication and collaboration environment; 0.976 for intention to quit work; and 0.943 for perception of organizational performance. Cronbach's alpha value is 0.870 for diversity climate 0.870 . This result indicating excellent internal consistency. Table 1 present result of the ANOVA (including the F-test and significance levels) and Independent $\mathrm{t}$-Test for the overall scale as well as for each of the variables in the research model. Table 2 is the complement of the Table 1 , presenting the means that showed significant differences for the interaction. 
Table 2: Results of Anova and Independent t-Test

\begin{tabular}{llllllll}
\multicolumn{1}{c}{ Independent Variable } & $\begin{array}{c}\text { Diversity } \\
\text { Climate }\end{array}$ & $\begin{array}{c}\text { Sob } \\
\text { Satisfaction }\end{array}$ & $\begin{array}{c}\text { Organizational } \\
\text { Commitment }\end{array}$ & $\begin{array}{c}\text { Intention } \\
\text { to Quit }\end{array}$ & $\begin{array}{c}\text { Cooperation and } \\
\text { Communication }\end{array}$ & $\begin{array}{c}\text { Behavioral } \text { Innovation } \\
\text { Organizational } \\
\text { Performance }\end{array}$ \\
\hline Political Identity (F value) & $14,67^{* *}$ & $17,81^{* *}$ & $13,84^{* *}$ & $15,37^{* *}$ & $4,47^{*}$ & $6,23^{*}$ & $2,65^{*}$ \\
Cultural Identity (t value) & $4,15^{*}$ & $4,1^{*}$ & $3,83^{*}$ & $2,68^{*}$ & $1,74^{*}$ & $2,38^{*}$ & $3,3^{*}$ \\
Religions Identity (t value) & $5,78^{*}$ & $4,26^{*}$ & $4,65^{*}$ & $5,68^{*}$ & $2,64^{*}$ & $3,47^{*}$ & $3,47^{*}$ \\
\hline${ }^{*}$
\end{tabular}

${ }^{*} \mathbf{p}<.05 .{ }^{* *} \mathbf{p}<.01$

With respect to research model, which deals with political identity differences in the diversity climate perception, Table 2 indicates that on average, conservative+nationalist employees $(M=3.22)$ had more positive perceptions than social democrat+socialist employees $(M=2.74)$. Religious identity in the diversity climate perception, sunni muslim employees $(M=3.58)$ had more positive perceptions than others (Alevi, atheist, deist, Christian $\mathrm{M}=2.36$ ). Cultural identity in the diversity climate perception, Turkish employees $(M=3.92)$ had more positive perceptions than others (Kurdish, Armenian, Immigrant $M=2.98$ ). A similar trend was revealed with respect to individual outcomes (Job satisfaction and organizational commitment) and organizational outcomes (intention to quit, cooperation and commucnication, behavioral innovation, performance).

Table 3: Mean Differences of the Independent Variables

\begin{tabular}{|c|c|c|c|c|c|c|c|}
\hline Independent Variable & $\begin{array}{c}\text { Diversity } \\
\text { Climate }\end{array}$ & $\begin{array}{c}\text { Job } \\
\text { Sativfaction }\end{array}$ & $\begin{array}{c}\text { Organizational } \\
\text { Commitment }\end{array}$ & $\begin{array}{c}\text { Intention } \\
\text { to Quit }\end{array}$ & $\begin{array}{l}\text { Cooperation and } \\
\text { Communication }\end{array}$ & $\begin{array}{l}\text { Behavioral } \\
\text { Innovation }\end{array}$ & $\begin{array}{l}\text { Organizational } \\
\text { Performance }\end{array}$ \\
\hline \multicolumn{8}{|l|}{ Political Identity } \\
\hline Conservative + Nationalist & 3,7261 & 3,7848 & 3,8326 & 3,3217 & 3,5217 & 3,9152 & 3,7118 \\
\hline Liberal & 3,0053 & 3,2044 & 2,9851 & 3,0263 & 3,0263 & 3,2123 & 3,5764 \\
\hline Social Democrat+Socialist & 2,7481 & 2,642 & 2,4924 & 2,1432 & 2,4432 & 2,8466 & 2,4405 \\
\hline \multicolumn{8}{|l|}{ Religious Identity } \\
\hline Sunni Muslim & 3,585 & 3,3558 & 3,6142 & 3,225 & 3,3495 & 3,2975 & 3,6381 \\
\hline Others & 2,3653 & 2,8772 & 2,6455 & 2,5841 & 2,1318 & 2,445 & 2,4865 \\
\hline \multicolumn{8}{|l|}{ Cultural Identity } \\
\hline Turkish & 3,9279 & 3,8695 & 3,846 & 3,4949 & 3,7238 & 3,96 & 3,9997 \\
\hline Others & 2,9884 & 2,9109 & 2,7171 & 2,7868 & 2,1811 & 2,0203 & 2,4363 \\
\hline
\end{tabular}

\section{DISCUSSIONS}

The goal of the present study was to investigate cultural, religional and political identity differences in the role of the diversity climate perceptions, individual career outcomes and organizational effectiveness outcomes. Integrating insights gleaned from a variety perspectives especially social identity theory and equity theory, we developed hypotheses concerning the relationship between employees' identity differences on the diversity climate perception, job satisfaction, organizatonal commitment, intention to quit, cooperation and communication, behavioral innovation, performance.

It is determined that cultural identity has a differentiating effect on perception of diversity climate, individual career outcomes and organizational effectiveness outcomes. In general, Turkish employees have a usually positive perception regarding the diversity climate. However, it is shown that the perceptions of employees who have Kurdish, Armenian and Immigrant cultural identities united in the category of others are significantly lower than Turkish employees.. For example, if we evaluate the negative perception among Kurdish group, it can be said that factors such as nationalism and alienation/marginalization are effective in this outcome, as Altun $(2013,78)$ stated in his research focused on the transformation of Kurdish identity into the Kurdish problem. Similarly, it can be said that Armenian employees have been subjected to discrimination due to both their ethnic origins and religious beliefs. In terms of individual career outcomes, Turkish employees have higher job satisfaction and organizational commitment compared to others. Likewise, Turkish employees who have higher job satisfaction and organizational commitment in terms of organizational outcomes have lower intention to quit from work, their perceptions about communication and collaboration environment are usually positive, their behavioral innovation perceptions are usually positive, and they have usually 
positive perception on organizational performance. It can be said that this situation is a natural result of the differentiation of perceived diversity climate according to cultural identity. When employees categorized as others/minority have negative perception regarding the diversity climate, it also increases the likelihood that they think their working environment as unfair, they have low confidence in management, do not have a sense of belonging to the organization and feels dissatisfaction, thereby increasing their intention to quit job. Various studies examining the impact of race and ethnicity on the perception of diversity support these results (Prahalad and Bettis, 1986; McKay et al. 2007; Cordova and Cervantes, 2010; Armenta and Hunt, 2009; Ely and Thomas, 2001; Ragin et al. 2012; Chua, 2013; Buttner et al. 2012; Chin,2010; Ellemers \& Rink, 2016). Buttner and Lowe, (2017, 179), stated that discriminatory and unfair practices increase their intention to quit of minority employees in workplace. In a similar study conducted with migrated workers in Australia and focusing on diversities in ethnic identity, it was found that the positive diversity climate affects their working attitudes, increases their emotional commitment and positively affects their psychological capital (Newman et al. 2018, 1).

It has been determined that religious identity has a differentiating effect on the perception of diversity climate. Sunni Muslims usually consider their working environment as an even factor supporting and showing respect to diversities. It is determined that the other religious groups, Alevi, Deist, Atheist, Agnostic and Christian workers, have occasionally positive perception regarding the diversity climate. It is determined that the organizational commitment of Sunni Muslim employees is usually high. It is found that organizational commitment and job satisfaction of employees belonging to other religious identities are occasionally low and their intention to quit is usually high. In terms of Turkish social structure, religious diversities in business life could bring about a series of negative consequences. It is difficult to determine the number of employees harassed or marginalized because of their religious identity in Turkey. However, as it is known, the practices of religious beliefs in the workplaces might cause tensions. There are strong findings indicating a negative perception towards other religious identities and the presence of sectarian conflicts in Turkey.On the other hand, there is discrimination against Alevis in the workplaces (Kayabaş \& Kütküt, 2011). Alevis' complaints regarding the discrimination they encounter are usually answered with the response of "oppressive tolerance". This means that all complaints of discrimination, all reminders for diversities are quietly slided over or completely denied. Besides the increasing presence and popularity of deists in Turkey is considered as the softened version of atheism by the government and religious institutions. They are also subjected to negative criticism (Girit, 2018).

It is determined that political identity has a differentiating effect on the perceived diversity climate. In addition, these differentiating effects have influence on both individual career outcomes and organizational effectiveness outcomes (except organizational performance). In this context, it is determined that employees with conservative + nationalist political identity have generally positive perception of the diversity climate, higher job satisfaction and organizational commitment compared to other identities. It is also determined that employees with social democrat + socialist identity occacionally have a positive perception on diversity climate, usually low job satisfaction and low organizational commitment. This situation is interpreted as a result of the transformations in the structural form of post-modern societies. Nowadays, the concept of "class inequalities" declines and gives way to inequalities and antagonisms shaped by the distribution of political power (Aktaş, 2011, 210). Given the fact that political power shapes perception, attitudes and behaviors in working life, the result of this research is not a coincidence: Employees of conservative + nationalist political identity have high individual career outcomes and organizational effectiveness outcomes and they diversity climate perception is usually positive. This finding coincides with the fact that political power suppresses, ignores and silences others as Heller and Feher (1988) stated in their book, "The Postmodern Political Condition".

As a result, this study which attempts to measure the perceptions shaping the attitudes and behaviors of employees with different identity structures, proceeded its tests $b$ means of quantitative research method and found its theoretical foresight supported.

\section{LIMITATION AND FUTURE RESEARCH}

There are several limitations of this study. The most important difficulties we encountered during the process of data collection in this study are the political and economic developments of Turkey during this same period, and employees refusing to respond or refuse to participate in the research because they have the fear and anxiety of losing their jobs.

It is also found that the participants who did not hesitate to express their gender, age, educational status, marital status which are described as superficial differences, -were concerned about giving information about their political identity, cultural identity and religious identity. The majority of associations, religious institutions and non-governmental organizations refused to participate in this study for inseure structure of Turkish society.

Furthermore, it is important to note that the social norms in the country, causing employees to be afraid to explain their sexual orientation, have a very negative impact on the data collection process. 
Last limitation may be regarded as the way that the survey is conducted. Online surveys make the data collection easier but it can lower the sincerity of the answers. . For this reason, it is presumed that the participants gave correct answers to the questions.

For a further study a research can be conducted on different identities and also different variables. . In addition, future studies could apply large-scaled studies for quantitative, qualitative or mixed research methods.

\section{CONCLUSION}

All participants of the labor market need to understand that people are diverse and unique, and that diversities are not sufficient to justify discriminatory policies such as exclusion, marginalization and humiliation. First and foremost we have to admit that people have equal rights despite their diversities. As a requirement of the modern managerial approach, it is necessary to focus on topics such as the function of leadership, career management and mentoring, training for diversity and sensitivity, employees' realm of freedom in order to reduce discrimination in working environment, to manage the diversities properly and create a supportive diversity climate.

\section{REFERENCES}

Adams, J. Stacy. (1963). Towards an Understanding of Inequity. The Journal of Abnormal and Social Psychology. 67(5): 422-436. DOI: https:/doi.org/10.1037/h0040968.

Agars, M.D., Kottke, J.L. (2004). Models and practice of diversity management: a historical review and presentation of a new integration theory, in Stockdale, M. and Crosby, F. (Eds), The Psychology and Management of Workplace Diversity, Blackwell Publishing, Oxford.

Akerlof, George, Kranton Richard. (1998). Identity and Economics. Mimeo University of California At Berkeley.

Aktaş, A. S. (2001). Türkiye Örneğinde Sınıf Analizleri ve Sınıf Şemaları. Toplum ve Bilim, 90, 210-228.

Armenta, B. E., Hunt, J. S. (2009). Responding to societal devaluation: Effects of perceived personal and group discrimination on the ethnic group identification and personal self-esteem of Latino/Latina adolescents. Group Processes \& Intergroup Relations, 12, 23-39. DOI:10.1177/ 1368430208098775

Arslan, M. (2015). How Does Postmodernity Exist as a Problematic of Philosophical Consciousness. Milel ve Nihal. 12.2: 55-72 DOI:.https://dergipark.org.tr/en/download/article-file/227383

Avery, Derek R., Volpone, Sabrina D., Stewart, Robert W., Luksyte, A., Hernandez, M., Mckay, P. F., He, M. R. (2013). Examining The Draw Of Diversity: How Diversity Climate Perceptions Affect Job-Pursuit Intentions. Human Resource Management. 52: 175-193. https://doi.org/10.1002/hrm.21524

Barutçugil, i. (2011). Kültürler Arası Farklııkların Yönetimi. İstanbul: Kariyer Yayıncılık.

Bauman, Z. (2017). Kimlik. Çev. Mesut Hasır. İstanbul: Heretik Yayıncılık.

Blum, M., Naylor, J. (1986). Industrial Psychology: Its Theoretical and Social Foundation. New York: Harper and Row.

Buttner, E. Holly, Lowe, Kewin. B.( 2017). Addressing Internal Stakeholders' Concerns: The Interactive Effect of Perceived Pay Equity and Diversity Climate on Turnover Intentions. Journal Of Business Ethics. 143: 12-33. https://doi.org/10.1007/s10551-015-2795-x.

Buttner, E. Holly., Lowe, Kewin. B., Billings H. Lenorra. (2010). Diversity Climate Impact on Employee of Color Outcomes: Does Justice Matter? Career Development International. 15(3): 23-38. https://doi.org/10.1108/13620431011053721.

Bynum, Leigh. A., Bentley, John. P., Holmes, Erin. R., Bouldin, Alicia. S. (2012). Organizational Citizenship Behaviors of Pharmacy Faculty: Modeling Influences of Equity Sensitivity, Psychological Contract Breach and Professional Identity. Journal of Leadership, Accountability and Ethics. 9(5):99111. http://www.na-businesspress.com/JLAE/bynum abstract.html.

Chin, J. L. (2010). Introduction to the special issue on diversity and leadership. American Psychologist 65: 150-156. https://doi.org/10.1037/a0018716.

Córdova, D., Cervantes, R. C. (2010). Intergroup and within-group perceived discrimination among U.S.-born and foreign-born Latino youth. Hispanic Journal of Behavioral Sciences. 32:259-274. https://doi.org/10.1177/0739986310362371.

Cox, T. (1993). Cultural Diversity in Organizations: Theory, Research, and Practice. San Francisco, CA: Berrett-Koehler.

Cropanzano, R., Andrew, L., Lehman, B. (2011). Peer Justice and Teamwork Process. Group \& Organization Management. 36(5): 567-596. https://doi.org/10.1177/1059601111414561. 
Dinler Kitabı (The Religions Book) 2016. Çev: Ahmet Fethi Yıldırım. İstanbul: Alfa yayıncılık.

Drach-Zahavy, A., Trogan, R. (2013). Opposites Attract or Attack? The Moderating Role of Diversity Climate in The Team Diversity-İnterpersonal Aggression Relationship. Journal of Occupational Health Psychology. 18: 449-457. https://doi.org/10.1037/a0033989

Ellemers, N., Rink, F. (2016). Diversity in Work Group. Current Opinion in Psychology. 11:49-53. https://doi.org/10.1016/j.copsyc.2016.06.001

Ensari M. Ş., Gürel A.P., Alay H.K.( 2017). Does Diversity Management Provide Competitive Advantage?. The International Journal Of Business \& Management . 5(1):101-113.

https://www.researchgate.net/publication/315487296 Does Diversity Management Provide Competitive Advantage.

Fassin, Y. (2012). Stakeholder Management, Reciprocity and Stakeholder Responsibility. Journal of Business Ethics. 109(1):83-96. https://doi.org/10.1007/s10551-012-1381-8.

Freeman, R., Huang, W. (2014). Collaboration: Strength in Diversity. https://www.nature.com/news/collaboration-strength-in-diversity-1.15912.

Gilbert, J.A., Stead, B.A., Ivancevich, J.M. (1999). Diversity management: A new organisational paradigm. Journal of Business Ethics 21(1): 61-76. https://doi.org/10.1023/A:1005907602028.

Girit, S. (2018). Türkiye'de Deizm Tartışması: Muhafazakar Gençlik Dinden Uzaklaşıyor Mu?. https://www.bbc.com/turkce/haberler-turkiye43832877.

Gonzalez, Jorge. A., Denisi, Angelo. S. (2009). Cross-Level Effects of Demography and Diversity Climate on Organizational Attachment and Firm Effectiveness. Journal of Organizational Behavior. 30: 21-40. https://doi.org/10.1002/job.498.

Gudykunst, William. B.(2015) Farklılıklar Arasında Köprü Kurmak. Çev: Kadir Asar. İstanbul:Kırmızı Yayınları.

Harrison, J. S., Freeman, R. E. (1999). Stakeholders, Social Responsibility and Performance: Empirical Evidence and Theoretical Perspectives. Academy of Management Journal. 42(5):479-485. https://doi.org/10.1002/job.498.

Hyde, C. A., Hopkins, K. (2004). Diversity climates in human service agencies: An exploratory assessment. Journal of Ethnic \& Cultural Diversity in Social Work, 13:25-43.https://doi.org/10.1300/J051v13n02 02.

Janice L. D., Robert Weech-Maldonadob, Dansky, Kathryn H. (2004). Racial and ethnic diversity and organizational behavior: a focused research agenda for health services management. Social Science \& Medicine. 59(5): 961-971. https://doi.org/10.1016/i.socscimed.2003.12.007.

Kaplan, D. M., Wiley, J W., Maertz, C. P. (2011). The Role of Calculative Attachment in The Relationship Between Diversity Climate and Retention. Human Resource Management. 50: 271-280. https://doi.org/10.1002/hrm.20413.

Kayabaş, E., Kütküt, Ö. M. (2011). Türkiye'de din veya inanç temelinde ayrımcılığın izlenmesi raporu [The report regarding the monitoring of discrimination based on faith and religion in Turkey]. İstanbul: Bilgi Üniversitesi yayınları.

Kossek, Ellen E, Zonia, Susan C. (1993). Assessing Diversity Climate - A Field-Study Of Reactions To Employer Efforts To Promote Diversity. Journal Of Organizational Behavior. 14:19-32. https://doi.org/10.1002/job.4030140107.

Lauring, J., Selmer, J. (2011). Multicultural Organizations: Does A Positive Diversity Climate Promote Performance?. European Management Review. 8(2): 124-141. https://doi.org/10.1111/j.1740-4762.2011.01011.x.

Lawler, Edward E. (1976). Control System In Organisations. Handbook Of Industrial And Organizational Psychology. ed: Dunneffer, May. Ray and Mcmally College Publishing. 1247 - 1281.

Maalouf, A. (2018). Ölümcül Kimlikler. Çev. Aysel Bora. İstanbul: Yapı Kredi Yayınları.

Madera, Juan, M., Dawson, May, Guchait, Priyanko. (2016). Psychological Diversity Climate: Justice, Racioethnic Minority Status and Job Satisfaction. International Journal Of Contemporary Hospitality Management. 28(11): 2514-2532. https://doi.org/10.1108/IJCHM-06-2015-0304.

McKay PF, Avery DR, Morris MA. (2009). A Tale Of Two Climates: Diversity Climate From Subordinates' And Managers' Perspectives And Their Role In Store Unit Sales Performance. Personnel Psychol. 62:4 767-791. https://doi.org/10.1111/j.1744-6570.2009.01157.x.

McKay, P. F., Avery, D. R. (2015). Diversity climate in organizations: Current wisdom and domains of uncertainty. In M. R. Buckley, A. R. Wheeler, \& J. R. B. Halbesleben (Eds.), Research in personnel and human resources management (pp. 191-233). Bingley, United Kingdom: Emerald Group. Mead, George H. 1934. Mind, Self, Society. New York.

Mor Barak, M. E., Lizano, Erica L., Kim, A., Duan, L., Min-Kyoung R., Hsin-Yi Hsiao, Brimhall, K. (2016). The Promise of Diversity Management for Climate of Inclusion: A State-of-the-Art Review and Meta Analysis, Human Service Organizations: Management, Leadership \& Governance, DOI: 10.1080/23303131.2016.1138915. 
Mollaer, F.(2014). Kimlik Politikaları: Tanınma, Özdeşlik ve Farklılık. Ankara: Doğubatı Yayınları.

Mor Barak, M.E. (2000). Beyond affirmative action: Toward a model of diversity and organizational inclusion. In M. E. Mor Barak \& D. Bargal (eds.), Social services in the workplace: Repositioning occupational social work in the new millennium (pp. 47-68). New York: Haworth Press.

Newman, C., Buesching H.,Macdonald W. D. (2003). Validating mammal monitoring methods and assessing the performance of volunteers in wildlife conservation- "Sedquiscustodietipsos custodies?". Biological Conservation 113(2): 189-197. https://doi.org/10.1016/S00063207(02)00374-9.

Orlando C, T. Barnett, S. Dwyer, K. Chadwick. (2004). Cultural diversity in management, firm performance, and the moderating role of entrepreneurial orientation dimensions. Academy of Management Journal 47(2): 255-266. https://doi.org/10.5465/20159576.

Özbilgin, M., Jonsen, K., Tatli, A., Vassilopoulou, J., Surgevil, O. (2013). Global Diversity Management. Oxford University Press.

Pamuk, A. (2017). Kimlik ve Tarih. İstanbul: Yeni Insan Yayınları.

Pitts, D. W., Wise, L. R. (2010). Workforce diversity in the new millennium: Prospects for research. Review of Public Personnel Administration 30:44-69. doi:10.1177/0734371X09351823.

Prahalad, C. K., Bettis R. (1986). The dominant logic: A new linkage between diversity and performance, Strategic Management Journal, 7(6):485501. https://doi.org/10.1002/smj.4250070602.

Reichers, A. E., Schneider, B. (1990). Climate and culture: An evolution of constructs. In B. Schneider (Ed.), Organizational climate and culture: 539. San Francisco: JosseyBass.

Richard, O. (2000). Racial diversity, business strategy, and firm performance: a resource-based view. Academy of Management Journal, 43(2): 16477. https://doi.org/10.5465/1556374.

Schneider, B. (2000). The Psychological Life Of Organizations. In N. M. Ashkanasy, C. P. M. Wilderom, \& M. F. Peterson (Eds.), Handbook of organizational culture and climate: xvii-xxii. Thousand Oaks, CA: Sage.

Sliter, M., Boyd, E., Sinclair, R., Cheung, J., Mcfadden, A. (2014). Inching Toward Inclusiveness: Diversity Climate, Interpersonal Conflict and WellBeing Women Nurses. Sex Roles. 71(1): 43-51. https://doi.org/10.1007/s11199-013-0337-5.

Smith C. Ann, Organ Deniss W., Near Janet P. (1983). Organizational Citizenship Behavior: Its Nature and Antecedents. Journal of Applied Psychology. 68(4): 653-663. https://doi.org/10.1037/0021-9010.68.4.653.

Sürgevil, O.(2010). Çalışma Yaşamında Farklılıkların Yönetimi. Ankara: Nobel Yayın Dağıtım.

Tajfel, H., Turner, J. C., Austin, W. G., Worchel, S. (1979). An integrative theory of intergroup conflict. Organizational identity: A reader, $56,65$. http://ark143.org/wordpress2/wp-content/uploads/2013/05/Tajfel-Turner-1979-An-Integrative-Theory-of-Intergroup-Conflict.pdf

Tett, Robert P., Meyer, John P. (1993). Job Satisfaction, Organizational Commitment, Turnover Intention and Turnover: Path Analyses Based On Meta-Analytic Findings. Personnel Psychology.46(2): 259-293. https://doi.org/10.1111/j.1744-6570.1993.tb00874.x

Thomas, RR Jr. (2010). World Class Diversity Management: A Strategic Approach. San Francisco, Calif: Berrett-Koehler Publishers.

Turner, J. C. (1985). Social Categorization and The Self. Concept: A Social Cognitive Theory of Group Behavior. Advances In Group Processes. Ed: E. J. Lawler. Greenwich, Ct: Jaı Press: 77-122.

Vandenberghe, C., Bonami, M., Jacquemyns, B .(1998). Perceived Support, Organizational Commitment, and Job Satisfaction As Correlates of Citizenship Behaviors: A Test in Retail Stores. Belgium: Press of Universite Catholique De Louvain, Louvain-La-Neuve.

Wang, C. L., Pervaiz K. A. (2004). The Development And Validation Of The Organisational Innovativeness Construct Using Confirmatory Factor Analysis. European Journal Of Innovation Management. 7(4): 303-313. https://doi.org/10.1108/14601060410565056.

Yavuz, Ç. (2010). İşletmelerde İnovasyon-Performans İlişkisinin İncelenmesine Dönük Bir Çalışma. Girişimcilik ve Kalkınma Dergisi. 5(2): 143-173. http://acikerisim.lib.comu.edu.tr:8080/xmlui/handle/COMU/348.

Yeo, S. (2006). Measuring organizational climate for diversity: a construct validation approach. PHD Dissertation. Graduate School of The Ohio State University. http://etd.ohiolink.edu/sendpdf.cgi/Yeo\%20Sheauyuen.pdf?osu114167766 